\title{
Epidemiology of human infections with highly pathogenic avian influenza A(H7N9) virus in Guangdong, 2016 to 2017
}

M Kang ${ }^{12}$, EHY Lau ${ }^{23}$, W Guan ${ }^{24}$, Y Yang ${ }^{1}$, T Song ${ }^{1}$, BJ Cowling ${ }^{3}$, J Wu ${ }^{1}$, M Peiris ${ }^{45}$, J He ${ }^{1}$, CKP Mok ${ }^{45}$

1. Guangdong Provincial Center for Disease Control and Prevention, Guangzhou, PR China

2. MK, EYL and WG contributed equally to this work

3. WHO Collaborating Centre for Infectious Disease Epidemiology and Control, School of Public Health, Li Ka Shing Faculty of Medicine, The University of Hong Kong, Hong Kong Special Administrative Region, PR China

4. State Key Laboratory of Respiratory Disease, National Clinical Research Center for Respiratory Disease, First Affiliated Hospital of Guangzhou Medical University, Guangzhou, PR China

5. HKU-Pasteur Research Pole, School of Public Health, HKU Li Ka Shing Faculty of Medicine, The University of Hong Kong, Hong Kong Special Administrative Region, PR China

Correspondence: Jianfeng He (hjf@cdcp.org.cn)

Citation style for this article:

Kang M, Lau EHY, Guan W, Yang Y, Song T, Cowling BJ, Wu J, Peiris M, He J, Mok CKP. Epidemiology of human infections with highly pathogenic avian influenza $\mathrm{A}\left(\mathrm{H}_{7} \mathrm{~N} 9\right)$ virus in Guangdong, 2016 to 2017. Euro Surveill. 2017;22(27):pii=30568. DOl: http://dx.doi.org/10.2807/1560-7917.ES.2017.22.27.30568

We describe the epidemiology of highly pathogenic avian influenza (HPAI) $\mathrm{A}\left(\mathrm{H}_{7} \mathrm{~N} 9\right)$ based on poultry market environmental surveillance and laboratory-confirmed human cases $(n=9)$ in Guangdong, China. We also compare the epidemiology between human cases of high- and low-pathogenic avian influenza $A\left(\mathrm{H}_{7} \mathrm{Ng}\right)$ $(n=51)$ in Guangdong. Case fatality and severity were similar. Touching sick or dead poultry was the most important risk factor for HPAI $\mathrm{A}\left(\mathrm{H}_{7} \mathrm{Ng}\right)$ infections and should be highlighted for the control of future influenza $A\left(\mathrm{H}_{7} \mathrm{~N} 9\right)$ epidemics.

A novel avian influenza $A\left(\mathrm{H}_{7} \mathrm{~N} 9\right)$ virus emerged in mainland China in March 2013, and 1,533 human infections with 592 deaths have been reported to the World Health Organization as of June 2017 [1]. The virus was low-pathogenic to poultry but caused varying disease severity in humans and there was an increase in virus detection in poultry and humans during winter [2-4]. There was a surge of human disease in the winter and spring period of $2016 / 17$ with more than 500 reported cases of influenza $A\left(\mathrm{H}_{7} \mathrm{~N} 9\right)$ [1], surpassing the maximum number (ca300 cases) of the previous four epidemic waves [5]. The 2016/17 epidemic wave has extended to summer and not yet come to an end at the time of writing, much longer than the earlier epidemics.

Before the 2016/17 winter wave, all influenza $A\left(\mathrm{H}_{7} \mathrm{Ng}\right)$ viruses identified from poultry and humans were lowpathogenic avian influenza (LPAI). However, influenza $\mathrm{A}\left(\mathrm{H}_{7} \mathrm{~N} 9\right)$ viruses isolated from two human cases in Guangdong in mid-February 2017 showed insertion of four amino acids at the cleavage site of the haemagglutinin protein, indicating that the virus had become highly pathogenic to chickens $[6,7]$. In this study, we report the prevalence of the highly pathogenic avian influenza ( $\mathrm{HPAl}) \mathrm{A}\left(\mathrm{H}_{7} \mathrm{~N} 9\right)$ virus in Guangdong poultry markets through active surveillance and compare the epidemiological characteristics and clinical outcomes between the patients infected with the HPAI and LPAI $\mathrm{A}(\mathrm{H} 7 \mathrm{~N} 9)$ viruses in Guangdong province during the 2016/17 season.

\section{Environmental surveillance for influenza $A(H 7 N 9)$ virus and detection of HPAI and LPAI A(H7N9) human cases}

Influenza $\mathrm{A}\left(\mathrm{H}_{7} \mathrm{~N} 9\right)$ infection is a notifiable disease in mainland China. From 1 November 2016 through 31 March 2017, a total of 60 RT-PCR laboratory-confirmed human influenza $A\left(\mathrm{H}_{7} \mathrm{~N} 9\right)$ cases were detected and reported to the Guangdong Provincial Center for Disease Control and Prevention (Guangdong CDC). All influenza $A\left(\mathrm{H}_{7} \mathrm{~N}\right.$ 9)-positive samples were sent to Guangdong CDC for further discrimination between HPAI and LPAI $A\left(\mathrm{H}_{7} \mathrm{~N} 9\right)$ viruses by sequencing the connecting peptide region of the haemagglutinin gene; nine HPAl and 51 LPAI A $\left(\mathrm{H}_{7} \mathrm{~N} 9\right)$ human cases were identified.

The $\mathrm{H}_{7}$ detection rate from environmental surveillance [8] in the Guangdong live poultry markets (LPMs) increased in December 2016, and there was a surge in the number of reported influenza $A\left(\mathrm{H}_{7} \mathrm{~N} 9\right)$ human cases starting in mid-December 2016 (Figure).

HPAI $A\left(\mathrm{H}_{7} \mathrm{~N} 9\right)$ viruses were first identified in poultry markets in four of 21 cities in Guangdong in November 2016; before that, only LPAI $A\left(\mathrm{H}_{7} \mathrm{~N} 9\right)$ viruses has been detected. The first patient infected with $\mathrm{HPAl} A\left(\mathrm{H}_{7} \mathrm{Ng}\right)$ viruses fell ill on 17 December 2016 (Figure) [9]. Genetic characterisation of $\mathrm{HPAl} \mathrm{A}\left(\mathrm{H}_{7} \mathrm{~N}\right.$ 9) was carried out in 
Epidemic curves for HPAI and LPAI A(H7N9) human cases, Guangdong province, 1 November 2016-31 March 2017 $(\mathrm{n}=60)$

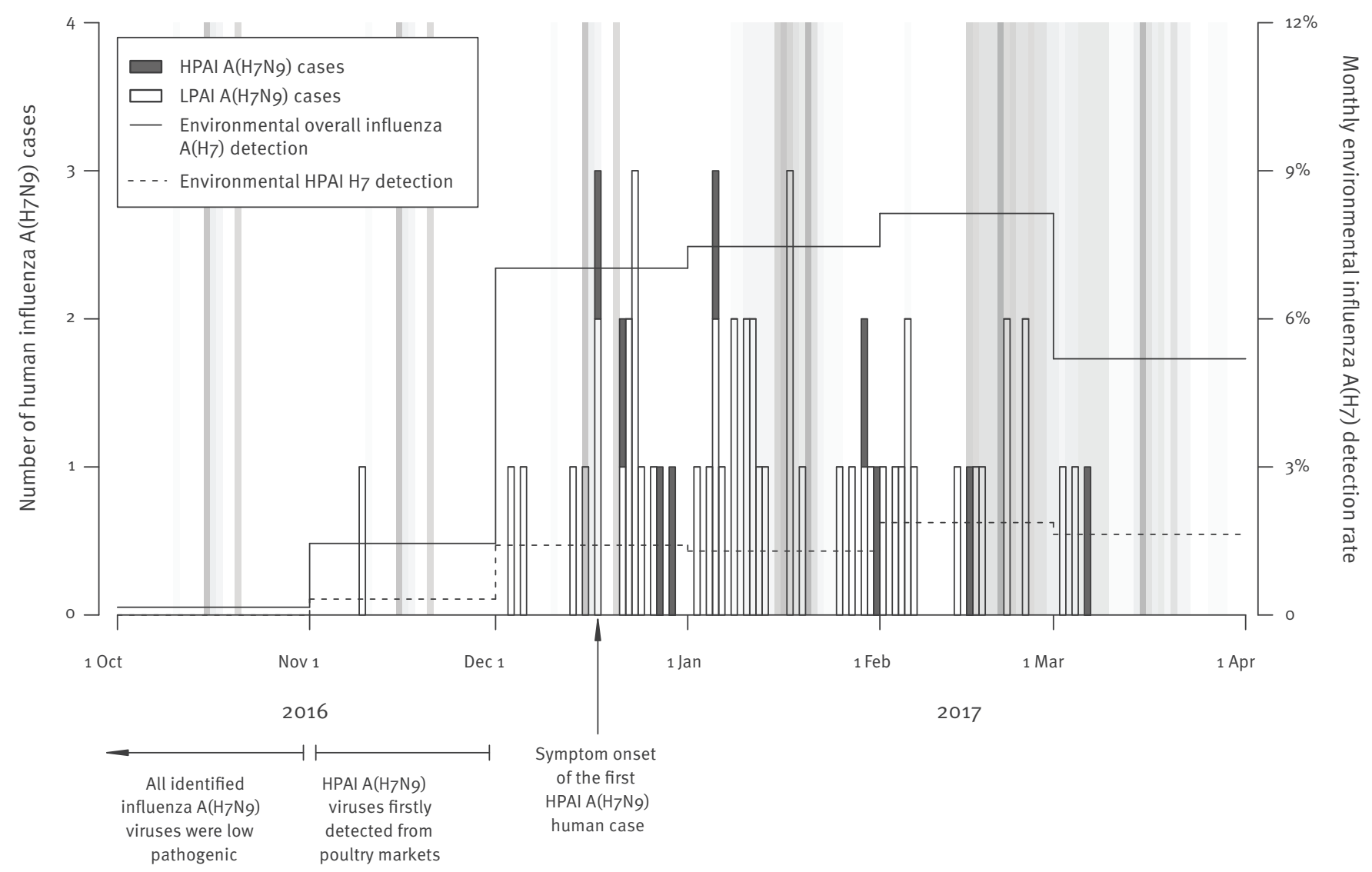

HPAI: highly pathogenic avian influenza; LPAI: low pathogenic avian influenza.

Grey bars: time when rest days or closure in poultry markets were implemented. Darker bars: more cities implementing the market interventions on the same day. Dashed line: monthly environmental influenza $\mathrm{A}(\mathrm{H} 7)$ detection rate from 105 poultry markets in Guangdong province.

retrospect and thus, LPAI and $\mathrm{HPAI} A\left(\mathrm{H}_{7} \mathrm{~N} 9\right)$ patients were managed in the same way. Different cities in Guangdong have implemented routine rest days in live poultry markets since 2013 and temporary market closure for 3 to 14 days was also introduced in late February 2017, when the demand for chicken subsided after the Chinese New Year holiday and an increased number of human influenza $\mathrm{A}\left(\mathrm{H}_{7} \mathrm{~N} 9\right)$ cases were reported in Guangdong and other provinces in China (Figure).

\section{Comparison of HPAI and LPAI A(H7N9)}

human cases in Guangdong

During the study period, influenza $\mathrm{A}\left(\mathrm{H}_{7} \mathrm{~N} 9\right)$ human cases were detected in 16 of 21 cities in Guangdong (Table 1).

We collected demographic, epidemiological and clinical data on influenza $\mathrm{A}\left(\mathrm{H}_{7} \mathrm{~N} 9\right)$ cases using standardised forms. Collection and analyses of data from influenza $\mathrm{A}\left(\mathrm{H}_{7} \mathrm{~N} 9\right)$ human cases were part of an ongoing public health investigation of emerging outbreaks and thus were exempt from institutional review board assessment in China [10]. Descriptive analyses were carried out and multivariable analysis was fitted to a limited set of exposure variables.

We compared the demographic characteristics of the hospitalised human cases infected with $\mathrm{HPAl} A\left(\mathrm{H}_{7} \mathrm{~N} 9\right)$ $(n=9)$ vs LPAI $A\left(H_{7} \mathrm{Ng}\right.$ ) virus $(n=51)$ (Table 2$)$. We found a higher proportion of $\mathrm{HPAl} \mathrm{A}\left(\mathrm{H}_{7} \mathrm{Ng}\right)$ cases who were female (HPAI: $55.6 \%$ vs LPAI: $25.5 \%$, Fisher's exact test $p=0.111$ ) and a lower proportion living in areas with strictly regulated poultry trading, where live poultry sales were banned and only trading of dressed or chilled poultry is allowed (HPAI: $0.0 \%$ vs LPAI: $23.5 \%$, Fisher's exact test $p=0.182)$. The median age was similar for HPAI and LPAI A(H7N9) cases.

The clinical presentation was similar and all reported influenza $\mathrm{A}\left(\mathrm{H}_{7} \mathrm{~N}\right.$ 9) cases were severe and required hospitalisation (Table 2). However, fewer HPAI than LPAI 
TABLE 1

Geographical location of the HPAI and LPAI A(H7N9)

human cases detected in Guangdong province, 1

November 2016-31 March $2017(\mathrm{n}=60)$

\begin{tabular}{|c|c|c|}
\hline City $^{\mathrm{a}}$ & $\begin{array}{c}\mathrm{HPAI} A(\mathrm{H} 7 \mathrm{~N} 9) \\
n=9\end{array}$ & $\begin{array}{c}\text { LPAI A(H7N9) } \\
n=51\end{array}$ \\
\hline Guangzhou & 1 & 12 \\
\hline Shenzhen & 0 & 6 \\
\hline Dongguan & 0 & 4 \\
\hline Foshan & 0 & 5 \\
\hline Zhanjiang & 0 & 0 \\
\hline Jieyang & 1 & 2 \\
\hline Maoming & 0 & 0 \\
\hline Shantou & 0 & 0 \\
\hline Huizhou & 0 & 4 \\
\hline Jiangmen & 0 & 5 \\
\hline Meizhou & 0 & 2 \\
\hline Zhaoqing & 2 & 1 \\
\hline Qingyuan & 2 & 1 \\
\hline Zhongshan & 1 & 3 \\
\hline Heyuan & 1 & 0 \\
\hline Shanwei & 0 & 1 \\
\hline Shaoguan & 1 & 1 \\
\hline Chaozhou & 0 & 3 \\
\hline Yangjiang & 0 & 0 \\
\hline Yunfu & 0 & 1 \\
\hline Zhuhai & 0 & 0 \\
\hline
\end{tabular}

HPAI: highly pathogenic avian influenza; LPAI: low-pathogenic avian influenza.

a By descending order of population size.

$\mathrm{A}\left(\mathrm{H}_{7} \mathrm{~N} 9\right)$ cases had underlying conditions (Fisher's exact test $\mathrm{p}=0.076)$. Significantly more HPAI $A\left(\mathrm{H}_{7} \mathrm{~N} 9\right)$ cases $(77.8 \%)$ raised backyard poultry compared with LPAI A(H7N9) cases (29.4\%; Fisher's exact test $\mathrm{p}=0.009)$. HPAI $A\left(\mathrm{H}_{7} \mathrm{~N} 9\right)$ cases were associated with touching live or dead poultry (Fisher's exact test $p=0.010$ and 0.005 respectively), while exposures to poultry markets were similar. By including touching live poultry and touching dead poultry respectively in two multivariable ridge logistic regression models along with raising backyard poultry, these exposures remained independently significant, and touching sick or dead poultry was the single most important risk factor for HPAI A(H7N9) infections (Table 3).

Fatality risks among hospitalised patients were similar and remained high (40-60\%) for both LPAI and HPAl $\mathrm{A}\left(\mathrm{H}_{7} \mathrm{~N}\right.$ 9) cases. Duration from hospitalisation to admission to an intensive care unit (ICU) $(p=0.052)$ and from hospitalisation to discharge $(p=0.049)$ were significantly longer for HPAI A(H7N9) patients. Among patients who died, more HPAI $\mathrm{A}\left(\mathrm{H}_{7} \mathrm{~N} 9\right)$ patients had duration from hospitalisation to death longer than 21 days (HPAl: 3/5 vs LPAl: 2/22; p-value $=0.030$ ).

\section{Discussion}

In this study, we described the prevalence of influenza $\mathrm{A}\left(\mathrm{H}_{7} \mathrm{~N} 9\right)$ viruses in Guangdong poultry markets during the 2016/17 season and compared the demographical, epidemiological and basic clinical characteristics between the HPAI and LPAI A(H7N9) human cases. Since the end of the study period, two more influenza $\mathrm{A}\left(\mathrm{H}_{7} \mathrm{~N} 9\right)$ cases have been identified in Guangdong but have yet to be characterised as HPAI or LPAI. Although the study was limited by a relatively small sample with $9 \mathrm{HPAl}$ and $51 \mathrm{LPAI}$ A(H7N9) cases, comparing HPAl and LPAI $\mathrm{A}\left(\mathrm{H}_{7} \mathrm{~N} 9\right)$ patients within Guangdong province provided a direct comparison by reducing potential impact of geographical heterogeneity in community exposure patterns to poultry, access to healthcare and clinical management [11].

We identified touching sick or dead poultry as the single most important risk factor for HPAI $\mathrm{A}\left(\mathrm{H}_{7} \mathrm{~N} 9\right)$ human infections, followed by raising backyard poultry and touching live poultry. Similar peptide sequences at the multiple basic amino acid cleavage site of HA have been reported for $\mathrm{H}_{7}$ viruses in Chile and Canada that were shown to be highly pathogenic in chickens by intravenous pathogenicity tests [12]. Moreover, a recent study demonstrated that the insertion of the four amino acids in this region enabled trypsin-independent infectivity of this virus [13]. This observation strongly implicates that the new identified $\mathrm{HPAl} A\left(\mathrm{H}_{7} \mathrm{~N} 9\right)$ virus has a high virulence phenotype in chicken. In general, HPAl viruses in poultry disseminate to multiple organs including muscle, whereas LPAI viruses are restricted to the respiratory and gastrointestinal tracts. Thus, $\mathrm{HPAl} \mathrm{A}\left(\mathrm{H}_{7} \mathrm{~N} 9\right)$ virus-infected poultry carcasses may be more infectious to humans than poultry infected with LPAI A( $\left.\mathrm{H}_{7} \mathrm{~N} 9\right)$. These findings support our analysis that the major route of transmitting the $\mathrm{HPAI} A\left(\mathrm{H}_{7} \mathrm{~N}\right.$ 9) virus to humans will be through the contact of sick or dead rather than healthy poultry. However, the pathogenicity of chickens with $\mathrm{HPAl} \mathrm{A}\left(\mathrm{H}_{7} \mathrm{~N} 9\right)$ infection needs to be investigated urgently.

Clinical outcomes were comparable between hospitalised HPAI and LPAI A(H7N9) cases, except that the time from hospitalisation to discharge were longer for HPAI A(H7N9) cases. The importance of avoiding touching sick and dying poultry should be highlighted to the public for the control of $\mathrm{HPAl} A\left(\mathrm{H}_{7} \mathrm{~N} 9\right)$. Among those raising backyard poultry, 10 of 22 reported touching sick or dead poultry, while none reported touching sick or dead poultry among the 38 not raising backyard poultry. Strengthening awareness of the risks of backyard poultry will be crucial in the control of future HPAI $A\left(\mathrm{H}_{7} \mathrm{~N} 9\right)$ epidemics, especially since recent $\mathrm{A}\left(\mathrm{H}_{7} \mathrm{~N} 9\right)$ cases have shifted to rural areas where backyard poultry is more prevalent [5].

We observed longer average hospital stays for HPAI $\mathrm{A}\left(\mathrm{H}_{7} \mathrm{~N} 9\right)$ patients although there was no difference in clinical progression and outcome between HPAI and LPAI $A\left(\mathrm{H}_{7} \mathrm{~N} 9\right)$ patients. However, since there was no 
TABLE 2

Characteristics of laboratory-confirmed HPAI and LPAI A(H7N9) human cases detected in Guangdong province, 1

November 2016-31 March $2017(\mathrm{n}=60)$

\begin{tabular}{|c|c|c|c|c|c|c|c|}
\hline \multirow[t]{2}{*}{ Characteristics } & \multicolumn{3}{|c|}{$\begin{array}{c}\text { HPAI A(H7N9) } \\
n=9\end{array}$} & \multicolumn{3}{|c|}{$\begin{array}{c}\text { LPAI A ( } \mathrm{H} 7 \mathrm{Ng}) \\
n=51\end{array}$} & \multirow[b]{2}{*}{$p$ value $^{b}$} \\
\hline & $\mathrm{n}$ & $\%$ & $95 \% \mathrm{Cl}^{\mathrm{a}}$ & $\mathrm{n}$ & $\%$ & $95 \% \mathrm{Cl}^{\mathrm{a}}$ & \\
\hline Median age (in years with IQR) & \multicolumn{2}{|c|}{57 years } & $45-63$ & \multicolumn{2}{|c|}{56 years } & $49-67$ & 0.780 \\
\hline Male sex & 4 & 44 & $14-79$ & $38 / 51$ & 75 & $60-86$ & 0.111 \\
\hline Poultry worker & o & 0 & $0-34$ & $3 / 51$ & 6 & $1-16$ & 1.000 \\
\hline Residence in area with strictly regulated poultry trading & o & o & $0-34$ & $12 / 51$ & 24 & $13-37$ & 0.182 \\
\hline \multicolumn{8}{|l|}{ Exposure to live poultryc } \\
\hline Any exposure to live poultry & 7 & 78 & $40-97$ & $30 / 51$ & 59 & $44-72$ & 0.460 \\
\hline Touched live poultry & 7 & 78 & $40-97$ & $15 / 50$ & 30 & $18-45$ & 0.010 \\
\hline Bought live poultry & o & 0 & $0-34$ & $15 / 50$ & 30 & $18-45$ & 0.095 \\
\hline Prepared live poultry & 3 & 33 & $7-70$ & $9 / 50$ & 18 & $9-31$ & 0.369 \\
\hline Consumed live poultry & 4 & 44 & $14-79$ & $12 / 50$ & 24 & $13-38$ & 0.236 \\
\hline Raising backyard poultry & 7 & 78 & $40-97$ & $15 / 51$ & 29 & $17-44$ & 0.009 \\
\hline \multicolumn{8}{|l|}{ Exposure to sick or dead poultryc } \\
\hline Any exposure to sick or dead poultry & 6 & 67 & $30-93$ & $5 / 50$ & 10 & $3-22$ & 0.001 \\
\hline Within $1 \mathrm{~m}$ of sick of dead poultry & 1 & 11 & $0-48$ & $0 / 50$ & 0 & $0-7$ & 0.153 \\
\hline Touched sick or dead poultry & 5 & 56 & $21-86$ & $5 / 50$ & 10 & $3-22$ & 0.005 \\
\hline Consumed sick or dead poultry & 1 & 11 & $0-48$ & $0 / 50$ & 0 & $0-7$ & 0.153 \\
\hline \multicolumn{8}{|l|}{ Exposure to poultry markets ${ }^{c}$} \\
\hline Visited retail LPM & 5 & 56 & $21-86$ & $31 / 50$ & 62 & $47-75$ & 0.726 \\
\hline Visited wholesale LPM & 1 & 11 & $0-48$ & $9 / 48$ & 19 & $9-33$ & 1.000 \\
\hline Visited dressed poultry market & o & 0 & $0-34$ & $1 / 48$ & 2 & $0-11$ & 1.000 \\
\hline \multicolumn{8}{|l|}{ Symptoms } \\
\hline Fever & 8 & 89 & $52-100$ & $47 / 51$ & 92 & $81-98$ & 0.570 \\
\hline Cough & 8 & 89 & $52-100$ & $44 / 51$ & 86 & $74-94$ & 1.000 \\
\hline Sore throat & 1 & 11 & $0-48$ & $13 / 51$ & 26 & $14-40$ & 0.671 \\
\hline Weakness & 6 & 67 & $30-93$ & $19 / 51$ & 37 & $24-52$ & 0.145 \\
\hline Muscle pain & 4 & 44 & $14-79$ & $10 / 51$ & 20 & $10-33$ & 0.193 \\
\hline Shortness of breath & 0 & 0 & $0-34$ & $6 / 51$ & 12 & $4-24$ & 0.578 \\
\hline Diarrhoea & o & 0 & $0-34$ & $2 / 51$ & 4 & $0-13$ & 1.000 \\
\hline Underlying conditions & 2 & 22 & $3-60$ & $29 / 51$ & 57 & $42-71$ & 0.076 \\
\hline Pneumonia & 9 & 100 & $66-100$ & $51 / 51$ & 100 & $93-100$ & 1.000 \\
\hline ICU admission & 8 & 89 & $52-100$ & $45 / 51$ & 88 & $76-96$ & 1.000 \\
\hline Died & 5 & 56 & $21-86$ & $22 / 51$ & 43 & $29-58$ & 0.718 \\
\hline Median incubation period ${ }^{\mathrm{d}}$ (in days with $95 \% \mathrm{Cl}$ ) & \multicolumn{2}{|c|}{5.2} & $2.8-9.7$ & \multicolumn{2}{|c|}{3.8} & $3.0-4.6$ & 0.619 \\
\hline \multicolumn{8}{|l|}{ Median durations (in days with IQR) } \\
\hline Onset to laboratory confirmation & & 3.0 & $6.0-11.0$ & \multicolumn{2}{|c|}{8.0} & $6.0-10.0$ & 0.700 \\
\hline Onset to hospitalisation & & 3.0 & $1.0-5.0$ & \multicolumn{2}{|c|}{4.0} & $3.0-5.0$ & 0.451 \\
\hline Hospitalisation to ICU admission & & .0 & $1.8-2.0$ & \multicolumn{2}{|c|}{1.0} & $1.0-2.0$ & 0.052 \\
\hline Hospitalisation to death & & 8.0 & $3.0-30.0$ & \multicolumn{2}{|c|}{8.0} & $5.3-11.5$ & 0.434 \\
\hline Hospitalisation to discharge & \multicolumn{2}{|c|}{29.0} & $26.8-37.0$ & \multicolumn{2}{|c|}{20.0} & $14.8-26.0$ & 0.049 \\
\hline
\end{tabular}

$\mathrm{Cl}$ : confidence interval; HPAI: highly pathogenic avian influenza; ICU: intensive care unit; IQR: interquartile range; LPAI: low-pathogenic avian influenza; LPM: live poultry market.

a Cls shown for percentages unless otherwise indicated.

b Fisher's exact test for categorical variables, Wilcoxon signed rank test for continuous variables, and likelihood ratio test under accelerated failure time model for incubation periods.

' In the 10 days before symptom onset.

${ }^{d}$ Based on log-normal distribution, accounting for interval censoring of poultry or LPM exposure. 


\section{TABLE 3}

Multivariable logistic ridge regression analysis of risk factors for HPAI compared with LPAI A(H7N9) human infections $(\mathrm{n}=60)$

\begin{tabular}{|l|c|c|}
\hline \multirow{2}{*}{ Exposure } & \multicolumn{2}{|c|}{$\begin{array}{r}\text { HPAI A(H7N9) infections } \\
\text { AOR }(95 \% \mathrm{Cl})\end{array}$} \\
\cline { 2 - 3 } & Model 1 & Model 2 \\
\hline Raise backyard poultry & $2.13(1.02-6.06)$ & $1.97(1.01-6.33)$ \\
\hline Touched live poultry & $2.11(1.01-5.76)$ & Not entered \\
\hline $\begin{array}{l}\text { Touched sick or dead } \\
\text { poultry }\end{array}$ & Not entered & $5.35(1.09-32.60)$ \\
\hline
\end{tabular}

AOR: adjusted odds ratio; $\mathrm{Cl}$ : confidence interval; HPAI: highly pathogenic avian influenza; LPAI: low-pathogenic avian influenza.

statistically significant difference in admission to ICU and clinical outcomes between HPAI and LPAI A(H7N9) patients, we still cannot determine whether the HPAl $\mathrm{A}\left(\mathrm{H}_{7} \mathrm{~N} 9\right)$ viruses caused higher severity in patients. That LPAI A(H7N9) patients had a shorter duration from hospitalisation to ICU admission and a smaller proportion with long duration from hospitalisation to death may be partially explained by the higher frequency of underlying conditions in this group. Detailed clinical investigation of virus shedding, virus dissemination and the levels of inflammation may be able to shed light on these questions.

Our analysis only focused on the comparison among severe influenza $\mathrm{A}\left(\mathrm{H}_{7} \mathrm{~N} 9\right)$ patients. In earlier epidemics, a spectrum of cases from of asymptomatic to mild and severe was detected in Guangdong [3], however in the more recent epidemic waves in China, the detected cases tended to be more severe [11]. Therefore, our understanding of the full range of severities of the HPAI $\mathrm{A}\left(\mathrm{H}_{7} \mathrm{~N} 9\right)$ infections is still incomplete.

\section{Acknowledgements}

This study was financially supported by National Natural Science Foundation of China (Grant no. 81761128014 \& 81490534), Science research project of the Guangdong Province (Grant no.2016A050503047), Municipal Science and Technology Bureau Foundation of Guangzhou (Grant no.2014Y2-00031), the Harvard Center for Communicable Disease Dynamics from the National Institute of General Medical Sciences (grant no. U54 GMo88558), Research Grants Council of the Hong Kong Special Administrative Region, China, through the Theme Based Research Scheme (Ref: T11-705/14N), Area of Excellence Scheme of the Hong Kong University Grants Committee (grant no. AoE/M-12/06), the Health and Medical Research Fund of the Hong Kong Special Administrative Region, China (grant no. RRG-11).

\section{Conflict of interest}

None declared.

\section{Authors' contributions}

CKPM and JH designed and organised the study. MK, WG, YY, TS, JW performed the study. MK, EHYL analysed the data and drafted the manuscript. BJC, MP, CKPM, JH revised the manuscript. CKPM and JH contributed equally to this work.

\section{References}

1. World Health Organization (WHO). Influenza at the humananimal interface: Summary and assessment, 17 May 2017 to 15 June 2017. Geneva: WHO; 2017. Available from: http:// www.who.int/influenza/human_animal_interface/Influenza Summary_IRA_HA_interface_06_15_2017.pdf?ua=1

2. Yu H, Cowling BJ, Feng L, Lau EHY, Liao Q, Tsang TK, et al. Human infection with avian influenza $A$ H7N9 virus: an assessment of clinical severity. Lancet. 2013;382(9887):13845. DOI: 10.1016/S0140-6736(13)61207-6 PMID: 23803487

3. Chen Z, Liu H, Lu J, Luo L, Li K, Liu Y, et al. Asymptomatic mild, and severe influenza $\mathrm{A}\left(\mathrm{H}_{7} \mathrm{Ng}\right)$ virus infection in humans, Guangzhou, China. Emerg Infect Dis. 2014;20(9):1535-40. DOI: 10.3201/eid2009.140424 PMID: 25148539

4. Wu J, Lau EHY, Xing Q, Zou L, Zhang H, Yen HL, et al. Seasonality of avian influenza $\mathrm{A}(\mathrm{H} 7 \mathrm{Ng})$ activity and risk of human $\mathrm{A}\left(\mathrm{H}_{7} \mathrm{N9}\right)$ infections from live poultry markets. J Infect. 2015;71(6):690-3. DOI: 10.1016/j.jinf.2015.08.007 PMID: 26365221

5. Wang X, Jiang H, Wu P, Uyeki TM, Feng L, Lai S, et al. Epidemiology of avian influenza $\mathrm{A} \mathrm{H}_{7} \mathrm{~N} 9$ virus in human beings across five epidemics in mainland China, 2013-17: an epidemiological study of laboratory-confirmed case series. Lancet Infect Dis. 2017;S1473-3099(17)30323-7.PMID: 28583578

6. European Centre for Disease Prevention and Control (ECDC). Genetic evolution of influenza $\mathrm{A}(\mathrm{H} 7 \mathrm{~N}$ ) $)$ virus in $\mathrm{China}-$ implications for public health. Stockholm: ECDC; 2017. Available from: http://ecdc.europa.eu/en/publications/ Publications/o9-mar-2017-RRA-update-6-influenza-A-(H7N9)China-Taiwan.pdf

7. World Health Organization (WHO). Human infection with avian influenza $\mathrm{A}(\mathrm{H} 7 \mathrm{~N}$ 9) virus - China. Geneva: WHO; 2017. Available from: http://www.who.int/csr/ don/27-february-2017-ah7n9-china/en/

8. Kang $M$, He J, Song T, Rutherford S, Wu J, Lin J, et al. Environmental sampling for avian influenza $\mathrm{A}\left(\mathrm{H}_{7} \mathrm{Ng}\right)$ in live-poultry markets in Guangdong, China. PLoS One. 2015;10(5):e0126335. DOI: 10.1371/journal.pone.0126335 PMID: 25933138

9. Zhang F, Bi Y, Wang J, Wong G, Shi W, Hu F, et al. Human infections with recently-emerging highly pathogenic $\mathrm{H}_{7} \mathrm{~N} 9$ avian influenza virus in China. J Infect. 2017;75(1):71-5. DOI: 10.1016/j.jinf.2017.04.001 PMID: 28390707

10. Cowling BJ, Jin L, Lau EHY, Liao Q, Wu P, Jiang $H$, et al. Comparative epidemiology of human infections with avian influenza $\mathrm{A} \mathrm{H}_{7} \mathrm{~N}_{9}$ and $\mathrm{H}_{5} \mathrm{~N}_{1}$ viruses in China: a populationbased study of laboratory-confirmed cases. Lancet. 2013;382(9887):129-37. DOI: 10.1016/S0140-6736(13)61171-X PMID: 23803488

11. Wu P, Peng Z, Fang VJ, Feng L, Tsang TK, Jiang $H$, et al. Human Infection with Influenza A(H7N9) Virus during 3 Major Epidemic Waves, China, 2013-2015. Emerg Infect Dis. 2016;22(6):964-72. DOI: 10.3201/eid2206.151752 PMID: 27191934

12. Network of Expertise on Animal Influenza. Influenza A cleavage sites. Paris: World Organisation for Animal Health; 2016. Available from: http://www.offlu.net/fileadmin/home/en/ resource-centre/pdf/Influenza_A_Cleavage_Sites.pdf

13. Zhu W, Zhou J, Li Z, Yang L, Li X, Huang W, et al. Biological characterisation of the emerged highly pathogenic avian influenza (HPAl) $\mathrm{A}\left(\mathrm{H}_{7} \mathrm{~N} 9\right)$ viruses in humans, in mainland China, 2016 to 2017. Euro Surveill. 2017;22(19):30533. DOI: 10.2807/1560-7917.ES.2017.22.19.30533 PMID: 28537546

\section{License and copyright}

This is an open-access article distributed under the terms of the Creative Commons Attribution (CC BY 4.0) Licence. You may share and adapt the material, but must give appropriate credit to the source, provide a link to the licence, and indicate if changes were made.

This article is copyright of the authors, 2017. 